\title{
Some Aspects of American Assistance to Russian Regions at the End of the Twentieth Century
}

\author{
Yuliya A. Tarasova \\ Svetlana V. Zhukova \\ Lyubov S. Bolshakova \\ Yelena Yu. Pantzeva \\ Samara State University of Economics, Syzran Branch, Russian Federation \\ Email: sangria80@yandex.ru
}

\section{Doi:10.5901/mjss.2015.v6n3s5p85}

\begin{abstract}
This article examines the role of the US in Russia's transition to democracy and market economy, US-Russian relations on the regional level and the influence of discontents in US-Russian political relations on their economic ties and US assistance programs to Russian regions. The authors discuss the reasons of technical assistance shifting from the centre to the Russian regions in 1997 and the implementation of Regional Investment Initiative there. Special attention is paid to American assistance programs in Samara region. Russian reforms were created in Washington but they were developing with greater difficulties than it was expected earlier by both sides. Deep changes in Russian foreign policy and American-Russian relations at the end of the twentieth century led to decreasing of American investments to Russian regions. Nevertheless, in authors' opinion, the RII Program played a significant role in social development of some Russian regions and broadening of the American-Russian "grassroot-level" ties.
\end{abstract}

Keywords: American-Russian relations; Gor-Chernomyrdin commission; regional investment initiative; Samara region; Novgorod region

\section{Introduction}

The American-Russian relations had the great influence on the development of the world community in the twentieth century. These ties played the major role both for Russia and the USA being at attention of researchers: historians, political scientists, sociologists and economists. The period from 1992 to 2000 was one of the most dramatic in Russian history. It took place with the direct participation of the American government. However, the hopes based on bilateral relations at the beginning of 1990-s came true only partially. By the end of this period, the American-Russian ties seemed to be close to new Cold War. Obviously, it is necessary to study the results of this short but very important period in the American-Russian relations. The main problems for discussion are the influence of the American support on improving the economic situation, formation of democratic institutes and civil society in Russia.

The political and economic relations at the state level drew close attention of contemporaries and researchers and they have been studied thoroughly nowadays. Many Russian researchers consider the inefficient economic cooperation between the US and the RF as the main reason of unstable political relations (e.g. see Batalov \& Kremenyuk, 2002; Melnikov, 2004). Anatoiy Utkin and Tatiana Shakleina highlighted that the RF role in the US foreign policy did not become as essential as the USSR was. The rank of the post-soviet Russia was much lower that is why the US could not build the real partnership relations with it (see Utkin, 2001; Utkin, 2003; Shakleina, 2006; for detailed analysis of the US economic potential and post-Communist Russia in the beginning of 1990s). The American political scientists Joseph Nye (2002) and David Rapp (1997) also stressed the weakness of the resources in Russian foreign policy. Russia played the passive role in these relations in the 1990s while the United States got the chance to use their power in building the new model of the world order (Nye, 2002; Rapp, 1997). According to Stephen Cohen (2000), the results of the foreign policy between the USA and the RF were oppressing. He blamed Clinton's administration in uninformed and ill-designed intervention in Russian transition to democracy and free-market economy during this period.

Obviously, the historiography of the American-Russian relations of this period seems to be narrow-minded because it investigates the political and economic ties at the interstate level. Meanwhile, the researchers do not pay much 
attention to the important aspects of internal political fight, which took place in both countries between supporters and opponents of closer cooperation and more equal relations.

One more disadvantage of the existing research papers is almost full oblivion of little but really important experience in development of the American-Russian relations at the regional level. The American-Russian relations at the regional level have not been fully analyzed yet. The economic development of different Russian regions was described in the paper of Åslund, and Olcott, 1999). Anders Åslund and Martha Brill Olcott (1999) investigated the consequences of regionalization in the country and the weak influence of the federal authority on the economic situation in Russia in the 1990s. It is clear that it is not enough to study the results of the US support for the Russian regions.

Most economic researchers evaluate the reforms in Russia and some other post-Soviet states as a great social experiment but they write about Regional Investment Initiative Program too rarely because of its poor results. The Regional Investment Initiative Program (RII) was created and developed by the President Clinton's Administration with the purpose of establishing the most effective institutes of the market economy in Russia. Its aims were to deepen and broaden US-Russian trade, to make some investments into education, culture and other spheres at the regional level. The circumstances of its initiation, activities and results are worth to be analyzed because it was also the experiment intended for evolutionary changes in economic culture of Russian entrepreneurs, authorities and intellectuals.

So, the authors are going to discuss three questions: the role of the USA in Russia's transition to democracy and market economy, US-Russian relations on the regional level, especially in the frame of Regional Investment Initiative, the influence of discontents in US-Russian political relations on their economic ties and the results of the RII Program for economic, cultural and social US-Russian cooperation.

To investigate these problems four methods of research were used: the analysis of archival data (the materials of the Departments of Samara Government, GAO Reports, etc.); the analysis of secondary sources (works of other researchers); running records (newspaper articles; ongoing series of statistical data). The last method included the analysis of interviews.

\section{American Assistance to Russia's Transformation}

In the beginning of the 1990s, the changes of political system and economy were necessary for Russia and its government was ready to accept financial and technical assistance of Washington, the International Monetary Fund (IMF) and the World Bank on any conditions. According to Zbigniew Brzezinski "international" financial institutes such as the IMF and the World Bank were American dominated (1998). We must agree with Joseph Stiglitz that "decisions on Russian reforms were made by small group of people, the officials of the IMF and the US Treasury" (2002, p. 170).

Western economic consultants in Russia and indigenous economists Yegor Gaidar and Anatolii Chubais tried to implement the market reform as quickly as possible. The prices were freed and the internal market opened for import of goods in 1992. Prices exploded with the inflation running at 1,600 percent by the end of 1992. Privatization was brought in Russia too fast and the way it was brought still discussed as the gift to the insiders. So, the first years of the reforms led to high prices, vanishing of people savings and conversion the state propriety to the oligarch's (Rutland, 2013).

As it was mentioned above, some researches gave negative assessment of the US policy towards Russia after the Cold War. They accused the Administration of President W.J. Clinton who took this post in 1993 in inadequate amount of the American assistance to Russia and using circumstances of post-soviet disorder for further weakening of the country (e.g. see Bystrova, 2009, p. 45-46):

At the beginning of reforms, the Russians hoped for the American support in the amount, compared with Marshall's Plan (when the United States helped to recover the West Europe economy after the World War II). Soon most people in Russia came to the conclusion that they wouldn't receive real help...Russia got on the market the flow of cheap and trifling goods such as chewing gum or low quality chicken legs in exchange for valuable raw materials.

Transfer of technologies was constrained by legislative obstacles. When Russia was trying to earn money on export of its own technologies such as delivery of rockets' engines to India, jet planes to Malaysia, the nuclear equipment to Iran, it was neglectfully stirred.

Some doubts about applicability of the American recommendations concerning reforms in Russia began to appear at that time. Western advisers who were working in the Kremlin and other government organizations in the early 1990s were accused in deliberate disorder of domestic economy and culture. It seemed that all the troubles of Russia were planned in Washington in advance and then fulfilled according to the CIA plans and their Russian supporters.

Michael Cox also wrote that the assistance given by the USA to the RF was inadequate to the promises. As the result of such policy, the economic reforms which were carried out without "a safety cable" led to fast narrowing of a social base of these reforms and the Russian government: 
The American failure or refusal to back economic reform with massive injections of US money had two rather unfortunate consequences. The first and least significant was to expose American rhetoric for what it was; so much hot air without little connection with Russian realities and needs. The second and more serious result, however, was to leave those who had initially backed the reforms inside Russia in an almost impossible position (2000, p. 263).

Nevertheless, the assistance was provided but probably, it was not enough for the formation of market economy and democracy in Russia in the shortest time. The IMF lend \$3 billion to Russia in 1993-94 in the form of a Systematic Transformation Facility, followed by $\$ 6.5$ billion standby loan in 1995, and a three-year, $\$ 18.5$ billion Extended Fund Facility in 1996. The World Bank lent $\$ 7.8$ billion to Russia in the 1990s for 33 projects, focusing on private sector development and infrastructure reform. The Russian government violated the conditions of the loans, especially with regard to cutting government spending (Rutland, 2013). We must note this violation was inevitable, reduction of government spending could be done only by reduction of pensions, salaries and other social obligations of the government. The position of pro-Western reformers in Russia was too weak to risk such radical measures.

The IMF and the World Bank assistance was not totally altruistic. The burgeon of payment for credits was laid on ordinary people. The US assistance was a better chance for Russia, because it need not to be returned. The amount of the financial support to Russia from the budget of the USA is shown in the Table 1.

Table 1. Funding for Major U.S. Programs with Russia since 1992 (in billions dollars)

\begin{tabular}{lccccccccc}
\hline Program/Fiscalyear & 1992 & 1993 & 1994 & 1995 & 1996 & 1997 & 1998 & 1999 & 2000 \\
\hline FreedomSupportAct & 0.09 & 0.31 & 1.00 & 0.36 & 0.22 & 0.14 & 0.21 & 0.16 & 0.18 \\
\hline CTR Nunn-Lugar DOD & 0.01 & 0.17 & 0.26 & 0.15 & 0.17 & 0.25 & 0.28 & 0.39 & 0.43 \\
\hline Agriculture & 0.13 & 1.03 & 0.03 & 0.03 & 0.02 & 0.01 & 0.00 & 1.16 & 0.20 \\
\hline Other & 0.02 & 0.04 & 0.03 & 0.02 & 0.14 & 0.19 & 0.22 & 0.42 & 0.25 \\
\hline
\end{tabular}

Source: United States General Accounting Office. Foreign Assistance International Efforts to aid Russia's Transition Have Had Mixed Results. November 2000, p. 169.

It must be noted that even this rather limited amount of financial assistance became the reason for critics of President Clinton's policy towards Russia by the conservatives during the elections in 1996. The leader of opposition, the Senator Robert Dole (Kansas) and the representatives of Republican Party in the Congress Richard Cheney, James Baker and Henry Kissinger were the most active in these critics. Generally, they accused the inefficient policy of Clinton in pouring the American taxpayers' money into the "rat holes" of the Kremlin without effective influence on the economic situation in the RF (Republican Foreign Policy..., 1996). In opinion of the opposition representatives, there was no middle class in Russia which would guarantee the continuous movement of the reforms in the country. The policy of Russia's involvement in the activity of international organizations (such as G-7) had born the illusions of Russia's status as the superpower. The RF tried to revive its influence on the republics of the former Soviet Union.

Possibly, this criticism was so rigid because of the pre-election fight. But partially it was justified. It became clear that Russia's transition to capitalism with the assistance of Washington and the IMF turned bad. According to Joseph E. Stiglitz (2002, p. 144): "radical reform strategy did not work: gross domestic product in the post-1989 Russia fell year after year. The stabilization/liberalization/privatization program was intended to set the preconditions for growth. Instead, it set the preconditions for decline. Not only was investments haltered, but capital was used up - savings vaporized by inflation, the proceeds of privatization or foreign loans largely misappropriated". He believed that the Clinton administration's Treasury and IMF experts misunderstood the real situation in the country, where the corruption was too disseminated to allow market economy work correct. However, it also became clear to the Administration of the President Clinton that the excessive support of the federal center led to negative results. It was decided to implement the RII Program which included financial, informational and technical support to several regions of the Russian Federation with the aim of attracting foreign investments there.

\section{Choosing the Participants for Regional Investment Initiative}

The beginning of the Program was declared at the meeting of US and Russian Presidents in 1997. The president Clinton promised to get additional financing in order to expand the American-Russian economic cooperation with emphasis on investment and exchange programs. They were supposed to create long and strong ties between young, highly educated people in Russian and American societies (Clinton, 1999, p. 345). The RII Program received the most part of funds under the Freedom Support Act. This Program was accepted with readiness by the Russian President Boris Yeltsin.

The choice of regions and the development of the implementation mechanisms were charged to the American- 
Russian Commission on economic and technological cooperation under the chairmanship of the Vice President of the United States Albert Gore and the Russian Prime Minister Viktor Chernomyrdin. In 1993-99, the Commission was almost the only institute of the American-Russian relations, which carried out economic cooperation, discussed pressing problems of trade and investments. Poor trade and economic relations between the countries greatly needed the patronage at the state level. It was also noted by Batyuk (2000).

Differences in industrial development of various regions of the Russian Federation, supplying with natural and human resources predetermined various degree of their appeal to the foreign capital. It should be noted that there were little number of regions with stable economic situation. Only 11 from 89 subjects of the Russian Federation were the "donors" of the federal budget. The number of the regions attractive to foreign investments was also very small. In 1995 eight Russian regions (Moscow, Tyumen Region, the Republic of Tatarstan, Nizhny Novgorod Region, Samara Region, St. Petersburg, Sakhalin Region and Tomsk Region) attracted $77.1 \%$ of all foreign investments (Rossiiskaya Gazeta, 1996). Moscow, large machine-building centers, raw regions and regions most closely located to foreign investors took the leading places in foreign investments inflow.

The weakness of legal and regulatory frameworks was the main obstacle to Russian reforms. As Joseph Stiglitz wrote:

"They try to take a shortcut to capitalism, creating a market economy without the underlying institutions, and institutions without the underlying institutional infrastructure. Before you set up a stock market, you have to make sure there are real regulations in place. New firms need to be able to raise new capital, and this requires banks that are real banks, not the kinds of banks that characterized the old regime, or banks that simply lend money to government. A real and effective banking system requires strong banking regulations. New firms need to be able to acquire land, and this requires a land market and land regulation" (2002, p. 139).

Improvement of the legislative base and the general investment climate also gave the opportunity to make the region more attractive to foreign investments. But the role of regional authorities in Russia's economic transition in the 90s seems to be ambiguous. According to Asslund and Olcott (1999), the actions of governors were one of the main reasons for political and economic disorder in the country. Regional authorities had enough power to introduce favorable laws for entrepreneurs on their territory or to make their work much harder. As Joseph Stiglitz wrote, "an oblast (regional government) like Novgorod, could use a host of regulatory and tax measures to extort "rents" from firms that operated in their jurisdiction. They were not kept from abusing their potential power by the rule of law" (2002, p. 158).

But there were some other ways of using the powers of regional authorities. According to the English researcher $\mathrm{Ph}$. Hanson (2001), some regional leaders had both desire and opportunities to carry out internal reforms in their regions. For example, the land regulation was easier to implement at the region than at the federal level, because the procommunist State Duma blocked such initiatives. Therefore, by the middle of the 1990s of the twentieth century the regions considerably differed in land legislation and taxation. Land transactions were legislatively resolved in Samara Region in 1997. The American investors paid great attention to the laws on the land existing in regions and tax privileges for investors.

At the beginning of the RII program, it was decided to implement it in two regions: Novgorod Region and the Far East (Khabarovsk territory). Though, they were not leading regions such as Moscow or Leningrad areas but rather stable with high income level of the population. Other peculiarities of these regions were the American-Russian trade and highly developed economic relations on their territories (Russia's foreign policy, 2001, p. 282.). So the choice of the regions was guided not only by the commitment of the governors to western democratic values and tendency to carry out market reforms but by the real economic potential and experience of cooperation already existing in the region with the American business. For example, Nizhny Novgorod Region which was headed by the well-known politician Boris Nemtsov till April 1997 also became the applicant for the participation in the RII. Nevertheless, the choice was made in favour of Samara region.

Its governor Konstantin Titov was not so famous in the West and had less influence on the Russian government but he managed to create investment climate which promoted the inflow of the American investments and building of the American-Russian joint-enterprises in Samara Region. There were 23 of them with participation of the American capital in 1997 here (see Table 2).

Table 2. Joint US-Russian enterprise in Samara region in $1990^{\text {th }}$

\begin{tabular}{cccccccccccc}
\hline Year & 1992 & 1993 & 1994 & 1995 & 1996 & 1997 & 1998 & 1999 & 2000 & 2001 & 2002 \\
\hline Number & 9 & 18 & 21 & 26 & 20 & 23 & 9 & 8 & 9 & 9 & 11 \\
\hline
\end{tabular}

Source: statistics data received from Samara Statistics Service. 
The US Department of State authorities wrote about Samara governor:

The administration has been aggressive and innovative in its efforts to improve conditions for investors, and to promote the development of a vibrant small business sector. Samara oblast was initially chosen for its proven commitment to economic reform and investment-friendly policy (Samara RI, Department of State, 2006).

It was also important that other region's enterprises manufactured the high-tech production such as space, aviation and automobile equipment. So, in September of 1997 Samara region was included in the list of regions where RII Program implementation was planned. Tomsk region was also lucky to take part in it in 1999.

\section{The RII Program Features and Results}

Though the political relations between the USA and Russia in 1995-96 were rather cold the shift of attention of the American administration from the federal center to the province opened many prospects for Russian regions' economic growth.

The growth itself was not the main aim of the Program. It was designed to set the infrastructure for the market economy. And the most important part was the work with people. As Brzezinski $(1998$, p.196) had put it, "history and culture matter for economic reforms too". Turning from federal centre and its elite, the American supervisors tried to find healthy parts of Russian society, interested in information and technologies for business-making, trade and management.

Due to the implementation of the RII program, offices of Business Information Service on the Newly Independent States (BISNIS) started to work in Khabarovsk territory, Novgorod and Samara regions (Americans are looking..., 2000, p. 38.).

Land and housing reforms, small business support and financing, investment promotion, small and micro-credits, non-government organizations support, community activity and partnership between US and Russian organizations took place in Novgorod Region in the frame of RII. Most effective results were achieved in land and real estate reforms (M.R. Miller, P. Hart and S. Butler, 1998). It should be noticed that other projects were also very meaningful. For example, the Women's Business Support Center was established in Staraya Russa for women entrepreneurs in order to increase the income of enterprises headed by women and their participation in public decision-making (Novgorod Regional Investment ..., 1998).

Seven million dollars became available to fund RII activities in Russian regions. About three million US dollars were given by the USAID to support the core programs of Novgorod Initiative. The first RII activities in Novgorod began in summer of 1997. Although the most activities were intended to end in December 1998, but some of them were going further (lbid).

On the territory of Samara region the RII project included the programs for business development such as financing of small and middle business, consulting services, regional development and attraction of investments, support of democratic initiatives (including the anti-corruption program), strengthening of social sector and health care, development of non-profit organizations and regional mass media, education and professional trainings the specialists of various branches. In 1999 most of them started to work. About 40 programs for technical support were fulfilled by 2000 within the Samara RII project. About US \$23 million were given for these program by the American partners (Apanius, 2002) and the regional government financed half of all the expanses.

The program which supported the use and application of Internet technology for US-Russian collaboration can be considered the most successful. It increased public access to Email and the Internet through the establishment of seven Public Access Internet Centers in Samara, Togliatti and Syzran. Program staff trained individuals and groups in the development, use and application of Internet resources. Specialists of the region worked with the staff to develop Russian-language information resources and training materials. The staff of the Project Harmony was working in order to enhance the telecommunication infrastructure with partner institutions and technology initiatives in Samara Region. It was awarded 30,000 USD in small grants to support local web projects (Hanson B., 2001).

The new reading room was opened for acquaintance with the American culture in 1999 in the frame of News Agency of RII and US Department of State American Corners program in Samara regional library. It was one of the first American Corner in Russia. It received the biggest collection of new American books (1160 copies). The readers got the chance to listen to the lectures on the American literature and culture and watch movies. The Club of graduates of the American programs was also created on the base of the American Corner. In a year, there were already more than 100 participants in it. They were the representatives of regional and city administrations, local mass media, members of different American organizations, teachers and tutors of the educational institutions of Samara region.

The exchange programs which allowed students and lecturers of the Russian Universities to train or conduct researches in the USA were of special importance. Carried out with financial support of the United States Agency for 
International Development (USAID) and administration of IREX (International Research \& Exchanges Board) they considerably expanded possibilities of interpersonal communications. The participants of the exchange programs with whom the authors managed to speak, highly appreciated the received knowledge and professional skills for the work and the experience of visiting the USA for the formation of their outlook. But some of the participants noticed their American partners' weak acquaintance with real life and culture of Russia. Sometimes it became the reason of misunderstanding between the Americans and Russians. Valeria Bondareva, who headed the International Department of Samara State Pedagogical University in 2007, told:

When I was studying my postgraduate course in Philadelphia in 1997 the American students did not take me for Russian. In their opinion, Russians seldom smile, do not like or are not able to communicate. At the same time, they were greatly interested in Russia. Sometimes there was the feeling that Americans were afraid of Russians. One of the teachers having learned that I was Russian told that several years ago she had prayed that Russians would not attack America (Interview with Valeria Bondareva, the Head of the International Department of Samara State Pedagogical University, 07.02.2007).

During the 1990s, the situation has changed. Contacts between students, teachers and scientists of the RF and the USA extended tremendously as it was described by Sazanova (2008). People in Russia and the US tried to understand their common problems and solve them. Cooperation of Russian and the American doctors from Sister Cities Samara and St Louis was also supported in the frame of Samara RII. But it began beforehand, in the middle of the 1990s. James Cox MD, the surgeon of Barnes Jewish hospital in St. Louis was the author of the original technique for treating vibrating and stable arrhythmia. In 1995, the Samara delegation headed by the professor Victor Polyakov MD went to St. Louis to study this technique. It became the beginning of two-year programme of collaboration between the Chair of the heart surgery of Samara Medical University and Barnet hospital. In October 1997, it came to the end and Samara doctors decided to perform such operation in their homeland. It was a success. Samara became the third center after Moscow and St Petersburg where such operations were performed (Interview with Victor Polyakov, MD, 31.05.2007.).

In 1997, St. Louis-Samara Sister Cities Committee and St. John's hospital sent the medical equipment for heart operations and the blood analysis to Samara. In 2000, the group of experts in emergency medicine from Samara visited American emergency centers and signed the cooperation agreement between the American Health Care Association and the Department of Health Care of Samara region. More medical equipment for Cardiological Center was delivered from St Louis to Samara in June 2002 (The Program of St. Louis Delegation's Visit to Samara, 15-19 June, 2002).

Formally, the RII program was carried out till 2002 but its most essential projects took place till the end of the ninetieth. It was influenced by the deterioration of the economic situation in Russia and the USA and intensive growth of tension in bilateral ties at the state level. The crisis of 1998 made the great impact on the international activity of the Russian regions. It did not affect the development of extracting industries; however, the income of manufacturing industries was strongly reduced. The direct foreign investments in the Russian economy were reduced too. That is why the results of the main trend of the Regional Investment Initiative (to promote economic growth in the Russian regions) became unclear.

However, the sharpening of the American-Russian relationships at the state level caused the biggest lack to the program. At the end of the nineties, each of the sides had serious reasons to suspect each other in bad intentions. NATO expansion to the East that began in 1996 revived traditional and quite reasonable fears of Russia for safety of its own territory. As Strobe Talbott wrote (2002), Clinton's conception of NATO considered Russia's accession in the future but in 1996, NATO's expansion was the core reason of tension in US-Russian relations.

Simultaneously promoting financial and technical assistance to RF the USA limited the flow of the Russian goods such as products of ferrous and nonferrous metallurgy and space branch on the American market (Crock, 1999). At the same time, the cooperation of Russia with Iran developing nuclear programme was a sore subject for the United States (Goldman, 2001). At last, the conflict in Kosovo and the American bombings of Serbia caused sharply negative reaction of Russia (Talbott, 2002, p. 353-369).

On the $24^{\text {th }}$ of March 1999, the Russian Prime Minister Evgeniy Primakov was flying to Washington to co-chair the Gor-Primakov Comission Summit. He ordered to turn the plane back to Moscow when had learned the US wouldn't stop bombing Serbia even during the Summit (Lapskii, 1999). The Prime Minister's reaction was completely supported in the homeland. But it caused the failure of regular session of the bilateral Gore-Primakov Commission, that is why the consequences of this situation were rather unfavourable. Though the majority of the RII projects were already either fulfilled or were in work, the conflict in political relations discredited the results of the Program and in many respects predetermined its ending. 


\section{The US-Russian Relations at the Edge of the Centuries and the End of the Program}

At the beginning of the twenty-first century, the new administrations of Vladimir Putin in Russia and George Walker Bush in the USA came to power. It started a new stage in the US-Russian relations, though it began with the internal transformations in Russia. The reform of local government which considerably strengthened the control of the federal center over the regions was carried out. This policy caused the concerns of Russia's return to authoritarianism. The article of Starobin (2000) was the ordinary example of such assessment.

As the result, it reduced their independence in cooperation with foreign partners. The collateral consequence of this reform became the dependence of the American programs in Russian regions from interstate relations. Economic growth allowed the Russian government to refuse the American support. Further activity of the American non-profit organizations such as the Peace Corp or the Open Society Foundation were forbidden in Russia. Some members of these organizations were accused in espionage activity on the territory of Samara Region (Samarskoye Obozreniye, 1997).

Such decisions showed the intention of the Russian government to limit intervention of the USA in domestic policy of the country. As Robert Legvold noted:

The problem, most Russians believe, arises because Russia has recovered its self-confidence, no longer cares to tolerate, in the words of one of them, "pedagogical relationship", has its own notion of what political forms will preserve national security and the country's way forward, and intends to pursue its interests in the outside world by its own light (2006, p.159).

Unfortunately, it also meant the impossibility of carrying out the RII program in other Russian regions. Tomsk region which was included in RII in 1999 did not receive technical assistance from the USA because there was no opportunity of its implementation in 2001.

\section{Concluding Remarks}

Observing the US assistance to Russian reforms in the 1990-s we may say the influence of this country was overwhelming and most of decisions on the way and the time of reforms were made in Washington. But it is demagoguery to blame all the ills of the transition such as falling of living standards in Russia, stagnation, inflation and the great rise of corruption on the US evil intension. Some other factors of history and culture played their negative roles.

In the 90s, the American-Russian relations were unstable, partly because of the absence of deep economic ties, trade and investment cooperation. Each side overestimated the opportunities of transition. The western researchers Roderic Lyne, Strobe Talbott and Koji Watanabe have put it that way:

There was an over-optimistic belief in the West, born in the euphoria of the end of the Cold War and the collapse of Communism, that, with Western goodwill, encouragement and active assistance, Russia could rapidly develop a market economy and her own model of democracy and take the place in the circle of advanced democracies appropriate for a country with Russia's cultural, intellectual, scientific and industrial strengths.

One of the bigger concerns was that, after seventy years of the command economy, Russia would not have the entrepreneurs necessary to make capitalism work. This, too, was a miscalculation. The skills required to survive and prosper in (or, more accurately, despite) the Communist system left Russia bursting with entrepreneurs. It was not there that the deficit lay, but in the absence or weakness of the institutions and laws to provide a fair environment for business competition. The adjustment to market economics, rough though it has been at times, has been a more rapid process than the development of a workable model of democratic government: on this, one Minister accurately described Russia to us as still being "in search mode". Democracies elsewhere have taken many years, sometimes hundreds of years, to develop. It is a process which, by definition, needs to be "bottom-up" more than "topdown" (Lyne et al., 2006, p. 149).

Nevertheless, the US support criticized both in America and Russia was necessary for the former Soviet Union transformations. Knowledge and skills received by young specialists in business, volunteer work, IT technologies were the positive results of the US assistance to Russian regions. The RII programs filled informational and technical gap between the Russian provinces and the developed countries of the world. Young people got the opportunity to learn the system of management in the USA to be convinced in efficiency of market economy and the appeal of democratic believes and values.

We can objectively estimate the consequences of any events only after some time. Our descendants would answer if the US support to Russia in the 1990-s was useful to the country and the world community. We hope that the experience of cooperation in the frame of Rll will be used for further development of the American-Russian relations. 


\section{References}

Americans are looking for business partners (2000). Volga-Biznes, 6. [Online] Available: http://www.volgabiz.ru/(February 05, 2015). [in Russian]

Apanius, A. (2002). Regional Initiative Supports Better Business in the Russian Provinces. BISNIS Bulletin.

Asslund, A., \& Olcott, M.B. (1999). Russia after Communism. Washington D.C.: Cambridge Endowment for International Peace.

Batalov, A.Ya., \& Kremenyuk,V.A. (2002). Russia and the United States: Rivals or Companions? SShA, Kanada: Economika. Politika. Kultura, 6, 19-36. [in Russian]

Batyuk, V.I. (2000). Gor-Chernomyrdin Commission: Birth, Life, Death, Resurrection? Pro et Contra, 2, 23-51. [in Russian]

Brzezinski, Zb. (1998). The Grand Chessboard: American Primacy and Its Geostrategic Imperatives. New York: Basic Books.

Bystrova, Yu. (2009). Russia - the United States: Rivals and Partners. Observer, 4, 45-46. [in Russian]

Clinton, W. J. (1999). Joint Statement on United States-Russia Economic Initiative. Public Papers of the Presidents of the United States. Government Printing Office.

Cohen, St. (2000). Failed Crusade: America and the Tragedy of Post-Communist Russia. New York, London: Norton.

Cox, M. (2000). From the Cold War to Strategic Partnership? US-Russian Relations since the End of the USSR. In: M. Boker, \& C. Ross (Eds.) Russia after the Cold War. London: Longman.

Crock, S. (1999). Washington Is Making It Hard For Russia to Help Itself. The Business Week, February 8.

Goldman, S. D. (2001). Russia. Washington D.C.: Congressional Research Service, Library of Congress. [Online] Available: http://digital.library.unt.edu/ark:/67531/metacrs1754/m1/1/high_res_d/IB92089_2001Apr19.html (April 17, 2007).

Hanson, B. (2001). American help gives real results. Volga-Biznes, 1. [Online] Available: http://www.volgabiz.ru/(February 01, 2011). [in Russian]

Hanson, Ph. (2001). Regional Income Differences. In B. Granville, \& P. Oppenheimer (eds.), Russia's Post-Communist Economy (pp. 419-445). Oxford: Oxford University Press.

Interview with Valeria Bondareva, the Head of the International Department of Samara State Pedagogical University (2007). [in Russian] Interview with Victor Polyakov, MD (2007). [in Russian]

Lapskii, V. (1999). So, Primakov in Washington. Rossiiskaya Gazeta, March 24. [in Russian]

Legvold, R. (2006). US-Russian Relations: an American Perspective. Russia in Global Affairs, 4, 157-170.

Lyne, R., Talbott, St., \& Watanabe, K. (2006). Growing Pains or a Paradigm Shift? Russia in Global Affairs, 4, $146-157$.

Melnikov, Yu. M. (2004). Russian-American relations: the main development trends. In P.T. Podlesny (Eds.) US policy in a changing world (pp. 107-124). Moscow: Nauka. [in Russian]

Miller, M.R., Hart, P., \& Butler, S. (1998). Novgorod Regional Investment Initiative Land and Real Estate Reform Sector. Final Report. [Online] Available: http://www.urban.org/UploadedPDF/411083_Novgorod.pdf (March 3, 2012).

Novgorod Regional Investment Initiative (RII). Progress Review. (1998). [Online] Available: http://pdf.usaid.gov/pdf_docs/pdabs544.pdf (March 3, 2013).

Nye, J.S. (2002). The Paradox of American Power: Why the World's Only Superpower Can't Go It Alone. Oxford: Oxford University Press.

Rapp, D. (1997). Contemporary International Relations. Frameworks for Understanding. Boston, London, Toronto, ets.: Pearson

Republican Foreign Policy Gurus Attack the Administration's Competence. (1996). The Washington Post, April 7.

Rossiiskaya Gazeta. (1996). March 12. [in Russian]

Russia's foreign policy: Collection of documents 1997 (2001). Moscow: Mezhdunarodnye otnosheniya. [in Russian]

Rutland, P. (2013). Neoloberalism and the Russian Transition, Review of International Political Economy, 20(2), 332-362.

Samara RI, Department of State (2006). Regional Initiative. [Online] Available: http://www.edc.samara.ru/ class/2001/galanov/index.html (April 10, 2007).

Samarskoye Obozreniye (1997). September 29.

Sazanova, N. (2008). American scientific, cultural and educational programs and Russian society in the 1990th. PhD thesis, Volgograd: University of Volgograd. [in Russian]

Shakleina, T.A.(2006). Russia and the United States in World Politics. SShA, Kanada: Economika. Politika. Kultura, 9, 3-18. [in Russian] Starobin, P. (2000). Let's Face It: Putin Is a Threat to Democracy. Business Week, July 3.

Stiglitz, J.E. (2002). Globalization and its Discontents. London: Penguin Books.

Talbott, St. (2002). The Russia Hand. A Memoir of Presidential Diplomacy. NewYork: Random House.

The Program of St. Louis Delegation's Visit to Samara, June 15-19, (2002). The International Relations with the Sister Cities of Foreign Countries, 3. Samara: Department of International and Interregional Relations of Administration of Samara.

Utkin, A.I. (2001). World Order in the XXI Century. Moscow: Eksmo. [in Russian]

Utkin, A.I. (2003). The American Empire. Moscow: Eksmo. [in Russian] 